\title{
Notes on Austrulian Curculionidae in the Berlin Museum. With descriptions of New Species.
}

By

Arthur M. Lea.

(Eingesandt im Dezember 1910.) 


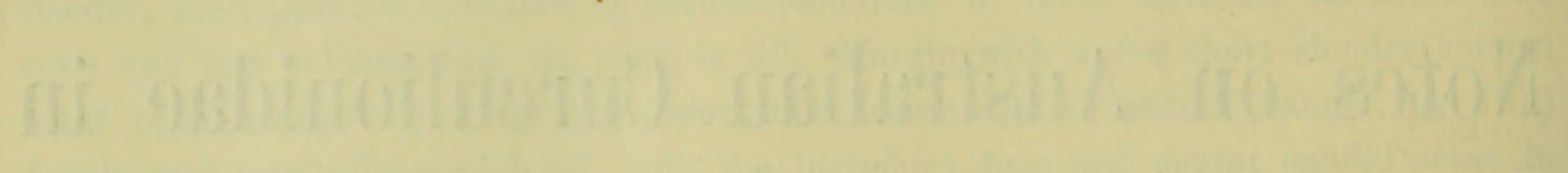

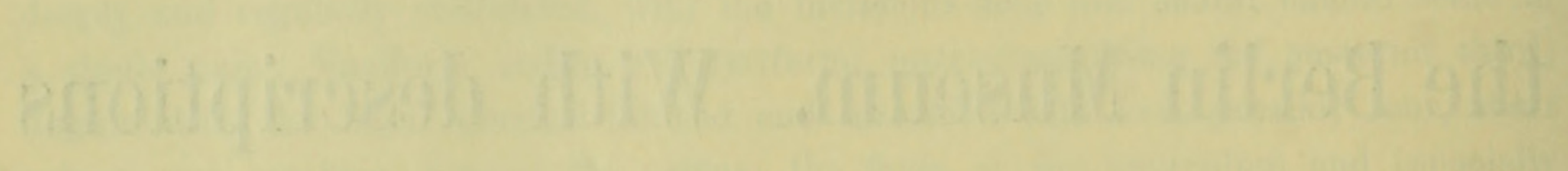

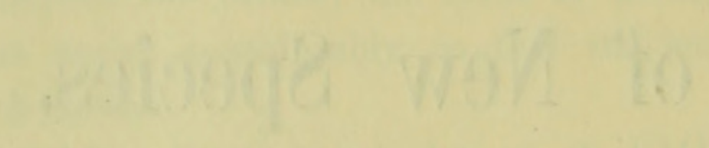


Professor H. Kolbe, of the Königliches Zoologisches Museum of Berlin, recently asked me to name some Australian weevils. Of most of the species single specimens were sent to me, and when such species were new, and not represented in my own collection, they were returned unnamed. When represented in my collection most of them were described, but from my own specimens, and the actual types are retained in my collection; the Museums own specimens being returned as co-types. In every instance at least one specimen of every species was returned. Following is a list of the named species, including descriptions of some new ones.

\section{Brachyderides.}

\section{Prypnus canaliculatus, Gyll.}

A small species fairly common in Victoria and southern New South Wales. The prothorax usually has a moderately impressed median line, but this may be altogether absent. As in other species of the genus the male is narrower and usually smaller than the female.

A specimen in the Berlin Museum is labelled (probably in error) as eoming from Queensland.

2. P. quinque-nodosus, Gyll.

3. P. squalidus, Gyll.

4. P. squamosus, Blackb.

5. P. trituberculatus, Germ.

6. Prostomus scutellaris. Fab.

7. Evas crassirostris, Pasc. Hab. - Swan River, Adelaide.

8. Evadodes lineatus, Pase.

9. Prosayleus comosus, Germ.

10. P. dispar, Germ.

11. P. Hopei, Sch.

12. Rhadinosomus Lacordairei, Pasc.

\section{Otiorrhynchides.}

13. Timareta granicollis, n. sp.

Black, appendages more or less red. Densely clothed with variously coloured scales, and with fairly numerous semi-decumbent setae.

Head with minute concealed punctures. Rostrum with sides very feebly incurved to middle; inter-antennary space narrowed behind so that at the base it is only about half the width of its apex; with a rather feeble carina, normally concealed on its hind half. Antennae rather thin; scape rather lightly curved; second joint of 
funicle slightly longer than first. Prothorax about as long as wide, sides evenly rounded, apex almost as wide as base; median line rather feeble; with numerous small partially concealed granules. Elytra subovate, nowhere paralled sided; with series of moderately large punctures, in rather feeble striae; interstices gently convex, not alternately raised. Front coxae touching at exact middle only; front femora stout; front tibiae feebly denticulate below. Length $5-6^{1 / 4} \mathrm{~mm}$.

Hab. - Australia (A. Bovie); W. Australia (Berlin Museum) Swan River, Darling Ranges, Pinjarrah (A. M. Lea).

The male differs from the female in being smaller, the elytra narrower, with larger punctures and the legs slightly longer.

T. figurata (which is also a very variable species) has the prothorax longer and without granules, and the head and rostrum smaller, with the inter-antennary space less narrowed hindwards and the elytra less convex.

Usually the femora are black or blackish and occasionally the tibiae as well; the apex of the prothorax is usually diluted with red, the red tip being noticeable even before abrasion. An occasional specimen has the entire derm diluted with red, but the claws are always black. On an occasional specimen the clothing is of an uniform dull slaty grey, but it is usually mottled. On most specimens the bulk of the scales on the upper surface are of a light-brown or fawn (sometimes with a faint golden gloss), feebly mottled with darker brown, and frequently with greyish white spots (at the summit of the posterior declivity often condensed to form a feeble fascia) scattered about. On some specimens the darker brown scales are entirely absent. On many there is a feeble dark spot on each side of the base of the prothorax, and these spots are occasionally curved round so as to meet in the middle of the disc. The suture is occasionally compicuously striped. On the under surface the clothing is mostly white or bluish-white. The femora are usually feebly annulated. From behind the elytral setae appear to be in a single row on most of the interstices.

Four specimens belonging to the Belgian Museum are labelled as from New South Wales, quite probably in error.

14. Celeuthetes echinatus, Fab.

15. Merimnetes oblongus, Blanch.

16. Myllocerus cinerascens, Pasc. Hab. - N. W. Australia: Carshalton.

17. IV. nasutus, Pasc.

18. Cherrus strigiceps, n. sp.

Black, antennae and tarsi more or less obscurely diluted with red. Densely clothed with light brown or somewhat ochreous scales. Upper surface rather sparsely setose; under surface and legs with rather numerous setae.

Head with numerous (but normally more or less concealed) longitudinal impressions on basal half. Rostrum stout, widely depressed along middle. Scape slightly shorter than rostrum; first joint of funicle less than twice the length of second. Prothorax moderately transverse; base almost truncate and distinctly wider than apex; with numerous almost regular and large granules or small tubercles. Elytra at base narrower than prothorax widest slightly before middle, where the width in 
male is equal to that of prothorax, but noticeably more in female; striate-punctate, punctures rather large but partially concealed; interstices with numerous small tubercles. Front tibiae with small but acute and sometimes recurved teeth. Length $8-13 \mathrm{~mm}$.

Female differs from the male in being larger, the elytra wider an legs and antennae somewhat shorter.

Hab. - S. Australia (Berlin and Nacleay Museums and A. Bovie), Adelaide (Belgian Museum) Mount Lofty (J. G. Otto Tepper); Victoria: Beaumaris (National Museum).

On nearly all the specimens the scales are almost entirely of a pale muddy brown colour, but they sometimes have a feeble golden gleam in parts, and are sometimes feebly variegated by small and slightly paler spots. The longitudinal impressions on the head are sometimes quite concealed, but they are often readily traceable before abrasion; they are also of variable length; as on some specimens they extend almost to the inter-ocular fovea. The prothoracic granules often appear to be obliquely arranged. The tubercles on the elytra, although very distinct, are never very large, and are more conpicuous on alternate interstices. On the suture they are present only about the posterior declivity.

In general appearance it is rather close to a species I have somewhat doubtfully identified as caenosus; but that species has a very distinct median carina on the rostrum, the prothorax and elytra more coarsely sculptured, and the clothing much less dense.

\section{Cherrus simplicipennis, n. sp.}

Colour and clothing, except that the setae on the upper surface are rather more numerous, much as in preceding species.

Head with numerous longitudinal impressions on basal half, but these normally almost or quite concealed. Rostrum stout, widely depressed along middle, with a very narrow median carina. Scape not much longer than rostrum, first joint of funicle not twice the length of second. Prothorax moderately transverse, sides strongly rounded, especially in female, base not much but distinctly wider than apex, disc somewhat flattened; with numerous almost regular granules. Elytra at base narrower than prothorax, widest near middle, where in male the width is usually slightly less than that of prothorax, but is distinctly wider in female; striate-punctate, punctures of moderate size but partially concealed; interstices almost uniform in width and convexity and without tubercles. Front tibiae wit a few small but acute teeth. Length $7 \frac{1}{2}-10^{1} / 2 \mathrm{~mm}$.

Female differs from the male in being larger, prothorax narrower, elytra wider and legs and antennae somewhat shorter.

Hab. - Australia (Entomological Society of Berlin); S. Australia (Berlin Museum), Adelaide (Belgian Museum and H. H. D. Griffith), Clifton, National Park, Highbury (Griffith).

In general appearance close to the preceding species and sculpture of head almost identical, but elytra without tubercles and prothorax flatter, with more numerous and smaller granules and considerably wider in the male. The median carina of 
the rostrum is also distinct; in the preceding species, if present, it is concealed except at the apex.

20. C. plebejus, Oliv.

21. C. ruficornis, Blackb. Hab. - Adelaide.

22. C. silaceus, Pasc.

23. Polyphrades biplagiatus, Pasc.

There is a single specimen, without a locality label, belonging to the Museum, that agrees with the description of this species, which is said to have "fronte distincte longitudinaliter plicata" and "elytris ... singulis pone medium plaga transversa alba fusco-marginata ornatis". Characters which render the species easy of identification. But there are also seven other specimens, before me, that were taken at King Georges Sound by W. George Masters." The type was recorded from Queensland. I think it very improbable that the species occurs in both places, and if the specimens before me are correctly identified (as I believe them to be) think it extremely probable that Queensland was given in error*).

The species is somewhat variable, as towards the base of the elytra there are sometimes spots of scales of the same colour as the conspicuous post-median spots; on the prothorax also there are sometimes feeble pale spots. The sculpture of the head is remarkable, and quite distinct before abrasion; there being either 11 or 13 longitudinal carinae. The size ranges from $1 \frac{1}{2}$ to 2 lines.

24. P. granulatus, Lea.

25. P. laticollis, Fhs.

26. P. nanus, Gyll.

27. P. paganus, Boh.

28. P. rostralis, Blackb.

29. P. setosus, Lea.

30. Mandalotus seticollis, Lea.

31. Catasarcus impressipennis, Boi.

32. C. rufipes, Fhs.

33. C. transversalis, Germ.

34. Stenocorynus neglectus, Lea.

35. Onesorus maculosus, Pasc.

36. Leptops Baileyi, Blackb.

37. L. colossus, Pasc.

38. L. corrugatus, Pase.

39. L. Duboulayi, Pasc.

40. L. ferus, Pasc.

41. L. robustus, Oliv.

42. L. setosus, Lea.

43. L. spinosus, Fhs.

44. L. tribulus, Fab.; L. tribulus, Fab. var. interioris, Blackb.; L. tribulus, Fab. var. obsoletus, Lea.

*) W. Pascoe in other instances has recorded undoubtedly West Australian species from Queensland, and vice versa. 
45. Catastygnus limbatus, Pasc.

46. C. scutellaris, Pasc.

47. Esmelina flavovittata, Pasc.

48. Ecrizothis Boviei, Lea.

\section{Amycterides.}

49. Psalidura cancellata, Ferg.

50. P. forficulata, Macl.

51. P. impressa, Boi.

52. P. rufolineata, Macl.

53. P. verrucosa, Macl.

54. Talaurinus ambiguus, Macl.

55. T. angustatus, Macl.

56. T. rudis, Macl.

57. T. rugifer, Boisd.

58. Sclerorrhinus Angasi, Macl.

59. S. bubalus, Oliv.

60. S. horridus, Macl.

61. S. sublineatus, Germ.

62. S. tristis, Boi.

63. S. tuberculosus, Macl.

64. S. vittatus, Macl.

65. Notonophes angulicollis, n. sp.

O Black. Densely clothed with short pubescence closely applied to derm; in addition with numerous brownish setae.

Rostrum about twice as wide as long; transversely impressed at base; with a narrow, deep impression at base; opening out in front into a deep triangular excavation; each side at base with an obtuse tubercle, representing a sublateral ridge; then with a longitudinal impression; with a strong ridge above each scrobe, the ridge deflected at the base, and raised so as to appear as a strong subconical tubercle above the eye. Scape fairly stout and rather strongly curved. Prothorax moderately transverse, sides angularly dilated at about apical third, the dilated portion with some conspicuous granules, apex slightly wider than base; with large, dense, irregularly distributed granules, rather larger and sparser at one third from apex than elsewhere; median channel rather feebly impressed. Elytra arcuate at base, each shoulder subtuberculate, base slightly wider than base of prothorax, sides slightly increasing in width to beyond the middle; with regular rows of large and comparatively shallow punctures; with small depressed granules, almost or quite absent from the first four or five sutural interstices on each side. Apical segment of abdomen with a rather large transverse excavation. Middle tibiae with a rather feeble subapical notch. Length (excluding rostrum) $13-17 \mathrm{~mm}$.

o Differs in having the elytra considerably wider and more ovate, apex with two small mucros, abdomen not excavated at apex, and middle tibiae without a notch.

Hab. - N. W. Australia: Behn and Upper Ord Rivers (R. Helms). 
A remarkable species which I refer to Notonophes solely on account of the tubercle over each eye as in cichlodes, the type of the genus. The projecting sides of the prothorax and peculiarly sculptured rostrum, as well as the tubercles, are also very distinctive features, whether the species be referred to Notonophes or Talaurinus.

A specimen belonging to the Berlin Museum is labelled "56807 Adelaide Schomb". Dr. Ferguson to whom it was shown, writes me that Adelaide probably means Adelaide River (N. Territory); he also informs me that he has a specimen from Princess Charlotte Bay (Queensland).

The clothing is very variable, and usually of a slaty grey, more or less mottled with brown. On the Museum specimen (a female) there is a large subtriangular dark patch on the side at about the middle of each elytron, the apex of the triangle almost touching the suture; the greater portion of the apical half of the posterior declivity has dark clothing, and there are several small patches elsewhere; its prothoracic clothing is mostly of a rather pale brown, with a conspicuous median stripe (which is continued on to the head for a short distance, where it divides a dark and somewhat velvety spot into two parts); its sides from the rostrum to apex of elytra appear to have numerous small black spots, owing to the absence of clothing from some of the punctures and granules.

The type specimens have the markings on the head and prothorax as in the Museum specimen, but on the elytra the irregular triangles are absent, as well as the apical blotch; the markings consisting of numerous feeble small mottlings, more noticeable towards the suture than elsewhere. On the elytra the setae are denser on the suture than elsewhere. The notch near the apex of the middle tibiae of the male is quite distinct from some directions, but invisible from others.

Two males from Port Darwin, which appear to belong to this species, differ in being smaller $(12 \mathrm{~mm})$ and somewhat narrower, with the dilated portion of the prothorax less angular, and its granules less conspicuous. The slaty grey clothing covers more of the surface, the velvety spots on the head are practically absent and the prothoracic clothing is almost uniform. The elytra have the apex and the median triangles somewhat as in the museum specimen, but the other markings absent. Their setae are also rather longer than in the other specimens.

\section{N. dumosus, Macl. \\ 67. N. spinosus, Macl.}

\section{Acantholophus tasmaniensis, n. sp.}

Black. Clothed with fine whitish setae or pubescence, giving the surface a greyish appearance; prothorax usually with a feeble whitish median line. Under surface with stiff blackish setae.

Head on each side at its junction with rostrum, with a strong, curved, subconical, simple tubercle. A subtriangular tubercle on each side of rostrum above middle of scrobe. Prothorax with a very irregular row of tubercles or large granules on each side of middle, the tubercles so disposed that six of them usually enclose a roughly circular median space; two small tubercles on each side of middle in front of subapical constriction, and one on each side of middle behind subbasal constriction, a small tubercle on each side of apex, a double tubercle (the front 
portion small) on each side in front of middle, and a single one behind middle; a few small granules scattered about. Elytra each with a treble row of rather small subconical tubercles, on the first two rows gradually increasing in size posteriorly, on the outer row decreasing; with fairly large but rather shallow punctures. each marked by small granules. Length $15^{1} / 2-16^{1 / 2} \mathrm{~mm}$.

Hab. - Tasmania: Dunalley (Berlin Museum) Hobart (A. M. Lea), Freycinet Peninsula (R. A. Black).

A specimen of this species was sent to Dr. Ferguson and he was asked to compare it with the type of gravicollis; in reply he wrote. "Not gravicollis, the prothorax has the first two granules the mesial row small and separate, and not confluent and raised as in gravicollis; the head spines are different also. Evidently belongs to Marshami group, but not that species". It is with considerable hesitation, however, that I describe the specimens before me as belonging to a new species rather than to a variety of gravicollis, more especially as two of them have the tubercle over each eye semidouble, but as their prothoracic granules are not as in typical specimens of gravicollis, it appears best to treat the species as distinct. It is the first of its genus to be recorded from Tasmania.

The inner row of tubercles on each elytron varies from six to nine (some of which, especially in the female, are very small) the median row from six to ten, and the outer from four to six. The female differs from the male in being larger and wider, with more ovate elytra and smaller tubercles. In both sexes the middle tibiae are not notched near apex.

69. A. Adelaidae, Waterh.

70. A. gladiator, Pasc.

71. A. gravicollis, Macl.

72. A. humeralis, Macl.

73. A. hystrix, Boh.

74. A. planicollis, Waterh.

75. A. scabrosus, Macl.

76. A. spinosus, Macl.

77. A. transitus, Macl.

78. Hyborrhynchus prodigus, Macl.

79. H. rugosus, Macl.

80. Amycterus Boisduvalii, Dup.

81. Cubicorrhynchus calcaratus, Macl.

82. C. crenicollis, Waterh.

83. C. Dohrni, Waterh.

84. C. gagates, Pasc.

85. C. maculicollis, Lea.

86. C. maximus, Macl.

87. C. morosus, D'Ur.

88. Mythites tuberculatus, n. sp.

Black. Upper surface with sparse brownish or black setae; under surface and legs with denser brownish or greyish setae; a ridge of brown setae entending from apex of abdomen (where it is shortest and sparsest) to between middle coxae. 
Head with three deep and wide grooves. Rostrum separated from head by a strong transverse depression; with a deep median channel; and on each side with another channel continuing the lateral groove of head, deep and rather wide at base, but narrow and running out in front. Prothorax not much wider than long, sides strongly rounded; with a deep and wide median channel, on each side of which is an irregular elevation, considerably thickened about its middle; surface elsewhere somewhat vermiculate, and with large irregular granules or small tubercles, frequently conjoined. Elytra with irregular rows of large punctures, becoming very large at sides; suture subcarinated at base; second interstice with a large obtusely conical tubercle just below summit of posterior declivity; third subcarinated near base, and projecting slightly on to elytra, with two or three (sometimes only one) distinct tubercles, of which the hind one is generally as large (although more obtuse) as the one on second; fifth with about three more or less median tubercles; seventh with about five or six; shoulders strongly projecting on the prothorax. Length (excluding rostrum) $11-15^{1 / 2} \mathrm{~mm}$.

of Differs in being wider, shoulders rounded and not projecting on the prothorax, apex with two small acute mucros, and under surface without a hairy ridge.

Hab. - Victoria: Melbourne (Berlin Museum and Entomological Society), Thorndale (National Museum), Portland (E. W. Ferguson); N. S. Wales (Macleay Museum); Tasmania: Brown's River (C. R. Findlay), Sandford (W. L. May).

The rounded shoulders of the female are quite sufficient to prevent this species from being confused with the females of sulcicollis, as in that species the shoulders are practically the same in both sexes. The specimen from the Entomological Society is marked Acanthomus basalis, Boi; but the species I identify as such (Mythites basalis, Boi) has the first and third interstices conjoined at the base, and (as also the shoulders) strongly produced in both sexes. Perfossus is described as having all the joints of the funicle transverse; degener as having only a single depressed carina in front. As it is the only species known to occur in Tasmania, it probably is the species on which Schoenherr founded the genus, and which be named tuberculatus (without giving a description, however).

Each front tibia of the male is somewhat inflated at the apex, with the under surface concave and densely and finely setose; but the inflated portion is much less conspicuous than in frater.

89. M. sulcicollis, Germ.

90. Bubaris pithecius, Pasc.

91. Euomus basalis, Boi.

92. E. Stephensi, Gyll.

93. Amorphorrhinus australis, Germ.

94. A. polyacanthus, Pasc.

95. Dialeptopus monachus, Pase.

96. D. plantaris, Pasc.

97. Tetralophus elevatus, Pasc.

98. Aedriodes fastigiatus, Pasc.

99. Ae. mendosus, Pasc. 
100. Ae. nodipennis, Boh.

\section{Ennothus fallax, Pasc.}

\section{Perperus parvicornis, n. sp.}

Black. Moderately densely covered with muddy-grey or mouse coloured scales, feebly variegated with paler spots towards the sides. In addition with more or less decumbent setae, similar in colour to the scales amongst which they are placed.

Head with small dense punctures, and with slightly larger ones scattered about, but both normally concealed. Rostrum comparatively stout, rather strongly curved; with an acute carina from base to apical triangle, with two feeble grooves on each side in addition to the scrobe. Antennae short; first joint of funicle distinctly longer than second, second distinctly longer than third, none of the others transverse. Prothorax moderately transverse, sides rather strongly rounded, apex lightly incurved to middle; with numerous small granules, each of which has a central puncture. Scutellum small but distinct. Elytra conjointly arcuate at base, widest about middle; in male about once and onefourth the width of prothorax, in female about twice as wide; with series of rather large punctures in feeble striae; interstices feebly convex, the third fifth and seventh slightly raised above the others; apex feebly notched. Second segment of abdomen scarcely, if at all, shorter than first, and slightly longer than third and fourth combined. Front tibiae rather strongly denticulate below. Length $8-11^{1} / 2 \mathrm{~mm}$.

Hab. - Tasmania (Berlin Museum), Hobart (on Leptospermum, A. M. Lea).

The female differs from the male in being larger, with considerably wider elytra and shortes legs.

A large species with the male even narrower than usual. Its prothoracic sculpture will distinguish it from all previously described species in which the first joint of the funicle is longer than the second. In malevolens*) the prothoracic granules are without punctures.

The antennae and tarsi are usually as dark as the other parts, but are sometimes obscurely diluted with red. The scales are very easily abraded and it is not at all uncommon to obtain specimens from which they are almost entirely lost from the upper surface; the setae, however, are not so easily abraded. On even fresh specimens, to the naked eye, the clothing is very dingy; but under a lens many of the scales, especially on the under surface and legs, have a golden or golden green gloss. The antennae, if drawn backwards, would scarcely extend to the middle of the prothorax. The prothorax usually has a feeble median line, but it may be absent.

\section{Perperus angustibasis, n. sp.}

Black, antennae and tarsi reddish. Densely clothed with greyish-white or fawncoloured scales, feebly or not at all variegated. With fairly, numerous, pale, decumbent setae, interspersed amongst the scales.

Head with small, normally concealed punctures. Rostrum slightly shorter than front tibiae; median carina thin and normally concealed. Antennae rather long and thin; first joint of funicle slightly longer than second, second distinctly longer than

*) This species was referred to in a footnote to the description of malevolens. 
third, the others gradually decreasing in length, but each distinctly longer than wide. Prothorax about as long as wide, sides rather strongly and evenly rounded, apex scarcely visibly incurved to middle; with a feeble median line. Scutellum absent. Elytra elliptic-ovate, at base no wider than base of prothorax, but much wider across middle than middle of prothorax; with series of moderate sized punctures in distinct striae; interstices convex, second and fourth wider than the others, suture (posteriorly) third and fifth feebly raised, third to sixth somewhat sinuous about middle. Second segment of abdomen shorter than first, but as long as two following combined. Front tibiae rather feebly denticulate below. Length $5^{1} / 2-8 \mathrm{~mm}$.

Hab. - Queensland (Berlin Museum).

The female differs from the male in being larger, with more strongly inflated elytra and shorter legs.

The elytra are narrowed to the base to an even greater extent than in convexipennis, but they are rather less convex than in that species, and are not prettily variegated.

Two of the four specimens before me have the tibiae and femora reddish as well as the tarsi; one of these has also the head diluted with red, and the other the head and elytra. The scales at the base of the head have sometimes a distinct golden or golden-green gloss. The two basal joints of the funicle are of almost even length, and from some directions the first actually appears to be the shorter, instead of being, as it is, really a trifle longer. The prothorax is rather strongly convex and appears (on abrasion) to be covered with large, flattened, more or less conjoined granules, causing the surface to appear somewhat vermiculate, but there are (at any rate on the disc) no true free granules.

\section{Perperus Couloni, Lea?}

Two somewhat abraded specimens labelled Nov. Holl. that I cannot distinguish from this species. It was originally described from King Island, but I have recently seen a Victorian specimen.

\section{P. malevolens, Lea.}

106. Methypora tibialis, n. sp.

Reddish-brown, in places blackish. Densely clothed with soft muddy-grey scales, becoming whitish, or at least paler on scutellum, posterior declivity and parts of the undersurface.

Head with dense concealed punctures. Rostrum about the length of prothorax, strongly grooved along middle, with a (usually concealed) fine carina in the groove, with a sublateral sulcus from near each antenna to side of eye. Antennae not extending to base of prothorax, second joint of funicle about once and one half the length of first. Prothorax diminishing in width to apex, basal two-thirds subparallel, depressed along middle, base strongly bisinuate, vermiculate-tuberculate. Elytra subparallel sided from near base to near apex, each strongly separately rounded at base; with rows of large, round, partially concealed punctures; interstices tuberculate or with short ridges in places. Legs long; femora clavate; four front tibiae strongly curved, hind pair compressed and slightly curved on the outer half. Length (including rostrum) $7 \frac{1}{2}-9 \frac{1}{2} \mathrm{~mm}$. 
Hab. - Queensland: Darling Downs (C. French); N. S. Wales: Gosford (H. J. Carter).

The clothing is so dense that the derm is almost everywhere concealed. In M. Carters specimens the scales are shining and of a beautiful golden colour. The three apical segments of the abdomen are covered with dark scales, but with three feeble stripes of paler scales; the second segment has pale scales ou its apical half, and darker ones on its basal half. All the elytral interstices from the third to the eighth (inclusive), have more or less distinct tubercles or short ridges, but the most conspicuous ones are about the posterior declivity as follows. A short ridge on the third terminating at summit, a longer and fairly acute ridge on the fifth terminating at summit, a similar one on seventh, and a strong conical tubercle at junction of fourth and fifth, about one third below summit; on each side of apex the margin is thickened, but scarcely in the form of tubercular swellings.

Readily distinguished from postica by its larger size, rougher and more parallel sided elytra without conical tubercles at apex, and shorter and rougher prothorax. The clothing is also very different.

\section{M. postica, Pasc. \\ 108. Oxyops Hopei, Boh.}

This is a widely distributed but apparently not a common species; specimens before me are from Townsville Cairns, Cape York and Adelaide. The specimen from Cape York (taken by Daemel) belongs to the Berlin Museum, and is densely covered with an ochreous meal; this probably being the normal condition of perfect specimens.

\section{Oxyops serricollis, Lea.}

The type of this species (as already noted) is certainly abraded, but these are now before me six other specimens from Adelaide (Berlin Museum), King Georges Sound (Macleay Museum), and Sea Lake, Victoria (Goudie). Of these two appear to have the clothing in perfect condition, on each of these there is a distinct antemedian fascia of white elongate scales, but not continuous to suture or sides; just beyond the middle on each side of the third interstice is a feeble fascicle. The King Georges Sound specimen is densely covered with an ochreous meal.

The species is rather close to irrasa, but differs in the less number of elytral fascicles, and the prothoracic granules smaller and les numerous; the rostrum is much the same in sculpture.

\section{Oxyops fasciculata, Redt.; O. maculata, Blackb.}

A common species in New South Wales and Queensland. I wrote to M. Blackburn that I considered his maculata to be a synonym and he replied: "Yes, maculata = fasciculata. I discovered it to be the case trongh N. S. W. specimens which I obtained some time ago".

111. O. bilunaris, Pase.

112. O. concretus, Pasc.

113. O. farinosus, Pase. 
114. O. serricollis, Lea. Hab. - Adelaide.

115. O. squamulosa, Boh.

116. Gonipterus crassipes, Lea.

117. G. scutellatus, Gyll.

118. Iptergonus cionoides, Pasc.

119. Bryachus squamicollis, Pasc.

120. Pantoreites scenicus, Pasc. Hab. -- Rockhampton.

\section{Diabathrariides.}

121. Aromagis echinata, Pasc.

122. Strongylorrhinus ochraceus, Schön.

\section{Aterpides.}

\section{Pelororrhinus interstitialis, n. sp.}

Dark reddish-brown, in places almost black. Densely clothed in places with white scales, having golden or opalescent gleams.

Head with dense partially concealed punctures, becoming coarse between eyes; crests wide, becoming conjoined in front. Rostrum curved, sides with irregular punctures becoming confluent in places; grooved along middle, groove with a strong carina at its base and two feeble ones at its apex, and bounded by strong carinae. Prothorax about as long as wide, sides strongly rounded; granulate-punctate; with a feeble median line. Elytra much wider than prothorax, parallel-sided to beyond the middle; with rows of large but more or less concealed punctures; alternate interstices raised; with rather numerous granules. Length (excluding rostrum) $11^{1 / 2}-15 \mathrm{~mm}$.

Hab. - Australia (Berlin Museum and Berlin Entomological Society); N. S. Wales: Liverpool (W. W. Froggatt), Blue Mountains (E. W. Ferguson), Sydney (A. M. Lea).

The scales densely and (except towards sides of metasternum) almost regularly clothe the under-surface; are dense about eyes, about junction of head and rostrum, on scutellum, form three lines on prothorax and are irregular on elytra. On the elytra they almost uniformly clothe the posterior declivity and sides, but elsewhere are in the form of spots varying in size, between the spots there are numerous nude spaces, caused by raised portions of the derm, and there appear to form two very irregular fasciae, one before and one across middle, but the fasciae are not clearly defined. The clothing is readily affected by immersion in fluids, and in any case becomes obscured with age, but on the under-surface, and especially on the abdomen, is most beautiful in fresh and perfect specimens. The first, second, fourth and sixth interstices have rather numerous granules; the third, fifth, seventh and ninth appear towards the base to be supplied with interrupted carinae, but beyond the middle the granules are much as on the others.

Close to margaritaceus, but rather more robust, with elytral clothing not linear in arrangement; and always with several nude or seminude spots, forming a feeble fascia beyond the middle; and the sixth interstice not uniformly clothed throughout. The scape is also slightly thinner, and the alternate interstices are 
more noticeably raised. On comparing a long series of both species together the differences of elytral clothing at once strike the eye, but the two are nevertheless very closely allied. Crassus and sparsus have the elytral interstices almost or quite uniform in elevation.

The species is common about Sydney on shrubs of the genus Leptospermum.

\section{P. argentosus, Gyll. Hab. - Queensland.}

125. Rhinaria elegans, n. sp.

Head (including crests), rostrum, prothorax, under-surface, appendages, scales (except in colour and pattern) and granules as in caudata, but elytra different at apex. Length $9-10 \mathrm{~mm}$.

Hab. - Australia (Berlin Museum); N. S. Wales: Sydney (A. M. Lea).

The sculpture of this species (except for its elytra) and the scales (except their markings) are almost exactly as in caudata, and I am in fact doubtful as to whether it should not be regarded as a variety of that species. The elytra however are much less constricted towards the apex, and scarcely notched. On the prothorax there are three feeble pale longitudinal markings, and several feeble spots. On the elytra there is a distinct dark brown triangle (rather pale towards the base, however), commencing on the shoulders, with its apex on the suture at the basal third; beyond this is an oblique pale (but not white) stripe, then a dark stripe slightly greater in width but somewhat diluted at suture; then another pale stripe almost (or quite) touching the suture, then an irregular dark triangle or angular space, which may or may not be connected with the dark median stripe. On the under-surface the clothing is mostly pale, but variegated with brown on the abdomen.

There are two specimens before me which agree almost exactly in the above very conspicuous markings; one of these belongs to the Berlin Museum, and bore the M. S. name which I have adopted.

On eleven other specimens (ranging in size from $7 \frac{1}{2}$ to $10 \mathrm{~mm}$ ) the scales of the upper surface are of an almost uniform muddy-brown; but on the prothorax vague spots can sometimes be seen, and on the elytra very indistinct and slightly darker spaces can be noticed.

On three other specimens the prothorax has the markings as on the types, but the elytra are vaguely mottled with pale and dark spots (but on one of these the spots are almost black).

On another specimen there are about eight pale spots on the disc of the prothorax, and on the elytra feeble pale spots are more or less conjoined, so as to form a feeble oblique stripe from near each shoulder to near the suture, just before the middle, another but very irregular one some distance beyond but parallel with the first, and a short oblique stripe on each side of the posterior declivity.

On still another specimen the clothing of the prothorax and elytra is mostly of a pale ochreous brown, but on the former there is or feeble and continuous median stripe (and no other markings), and on the latter there are a number of dark spots scattered about from the basal third to about the middle. With large irregular spaces slightly paler than other large spaces. 
On all eighteen specimens, however, the elytral interstices are each clothed with a more or less distinct row of stout yellowish or somewhat golden depressed setae; and they all have the shoulders very slightly produced.

The species is a widely distributed, one as there are specimens before me from Queensland (Brisbane and Stradbrooke Island), N. S. Wales (Galston, Sydney, Albury and Jenolan), Victoria (Bright), S. Australia (Adelaide und Fulham) and Tasmania (Jordan River).

126. R. caliginosa, Pasc.

127. R. concavirostris, Lea. Hab. - N. W. Australia: Carshalton.

128. R. caudata, Lea.

129. R. cavirostris, Pasc.

130. R. faceta, Pasc.

131. R. granulosa, Fhs.

132. R. pulicosa, Lea. Hab. - Adelaide.

133. R. sulcirostris, Lea.

134. R. tibialis, Blackb.

135. Aterpus griseatus, Pasc.

136. A. cultratus, Fab.

137. Aesiotes notabilis, Pasc.

138. Iphisaxus asper, Pasc.

139. Ethemaia sellata, Pasc.

\section{Hyphaeria geometrica, n. sp.}

Black, in parts reddish. Very densely clothed with scales, and in addition with stout setae.

Head flat. Eyes almost entirely invisible from above and very flat. Rostrum almost flat, continuous with head. Prothorax almost as long as wide, sides feebly rounded; with large, round, partially concealed punctures. Elytra about once and two thirds the width of prothorax, parallel-sided to near apex; third fifth and seventh interstices distinctly raised: third with a small tubercle at summit of posterior declivity; fifth with a small one at summit and another nearer apex; with traces of a few very feeble tubercles elsewhere; with rows of large, round but more or less concealed punctures. Under surface with large but more or less concealed punctures.

Under surface with large but more or less concealed punctures. Length (excluding rostrum) $4^{1 / 4}-5^{1 / 4} \mathrm{~mm}$.

Hab. - S. Australia: Adelaide (Berlin Museum); Victoria: Birchip (J. C. Goudie and H. H. D. Griffith); N. S. Wales: Coolabah (W. B. Gurney), Moree (D. Dumbrell).

From apex of rostrum to base of head the sides are almost perfectly parallel, the eyes making no difference, whatever, to the outlines; that is, when the autennae are at rest; but when they are drawn ont there is a slight but distinct subtriangular notch at the pit of each scrobe. From the sides the eyes appear to be perfectly flat; but they really cut into the lower surface of the head to a slight extent. In assimilis there is a very distinct dilatation at the eyes, although from above the eyes themselves are almost invisible. 
The clothing is so dense that the derm is everywhere concealed; but the autennae, tarsi, tibiae, elytra and sometimes the abdomen, are more or less red, the other parts being blackish. On most of the nine specimens before me the scales are of a pale muddy brown, with feeble spots or stripes of paler or darker scales. On two specimens (and less noticeably on a third) the paler scales have a distinct golden gloss. On three specimens there is a pale fascia just before summit of posterior declivity, quite distinct to the naked eye, but obscure under a lens. On all of the specimens a pale median stripe is present on the prothorax, and sometimes a less distinct stripe is present on each side. The setae cause an appearance as of a very feeble crest above each eye. The three tubercles on each elytron, at and about the summit of posterior declivity, are placed so as to form an equilateral triangle.

\section{Cleonides.}

\section{Lixus tasmanicus, Germ.}

\section{Hylobiides.}

\section{Aclees porosus, Pasc.}

143. Eurhamphus fasciculatus, Shuk.

144. Orthorrhinus cylindrirostris, Fab.

145. O. Klugii, Pasc.

146. O. meleagris, Pasc.

147. O. aethiops, Boi.

\section{Erirrhinides.}

\section{Meriphus granulatus, n. sp.}

Of a rather light reddish-castaneous; tibiae and base of femora flavous; head, prothorax (base and apex excepted), scutellum and sterna deeply infuscate or piceous; base and tip of rostrum, club and some spots on elytra more lightly infuscate. Moderately densely clothed with fine flavous (in some parts almost golden) setae, and which on the prothorax form four feeble but continuous lines from base to apex; elytra in addition wit stout suberect setae, each arising from a small granule.

Head longer than wide. Rostrum thin, feebly curved, about as long as head and prothorax combined; with five narrow carinae to middle, with the median one continued backward to between the eyes; apical half with fine punctures. Antennae thin, two basal joints of funicle elongate, first slightly longer than second. Prothorax slightly wider than long, base wider than apex, sides gently incurved towards base and apex; with a few small granules. Elytra twice the width of prothorax; shoulders prominent; sides feebly diminishing from shoulders to near apex, which is widely rounded; striate-punctate, punctures fairly large but partially concealed; suture, third, fifth and seventh interstices each with a row of small granules, second fourth and sixth with a few slightly larger and infuscated granules. Femora stout and strongly dentate, especially the hind pair; hind tibiae strongly curved. Length (excluding rostrum) $4-4^{1} / 4 \mathrm{~mm}$.

Hab. - Queensland (Berlin Museum); N. S. Wales: Wollongbar (R. Helms) 
Differs from description of umbrinus (the only species previously recorded from Queensland) in being larger and not uniformly coloured. The elytra are shorter and wider than in any other species known to me, except longirostris, but they appear to be wider even than those of that species, this being really due to the prothorax being decidedly narrower, with its sides less rounded.

The dark spots on the elytra (some of which are granules) are distributed in two very irregular bands, one at basal third and the other just beyond the middle. On the Queensland specimen the spots towards the base are conjoined so as to form a fascia, which, however, does not extend to the suture; this specimen also has the tarsi slightly infuscated.

149. M. fullo, Er.

150. M. guttatus, Pasc.

151. Desiantha caudata, Pasc.

152. D. irraea, Lea.

153. D. maculata, Pasc.

154. D. vegrandis, Lea.

155. D. vittata, Blackb.

156. Anorthorrhinus apicalis, Lea.

157. A. pictipes, Blackb.

158. Cyttalia tarsalis, Blackb.

159. Storeus majusculus, Blackb.

160. S. variegatus, Fab.

161. Nemestra incerta, Pasc.

162. Rhaciodes bicaudatus, Boi.

163. R. dentifer, Boh.

164. R. granulifer, Chev.

165. Aoplocnemis guttatus, Pase

166. A. phaleratus, Er.

167. A. suturalis, Pasc.

168. Eristus Blackburni, Lea.

169. Dicomada Obsti, n. sp.

Black, elytra (except about base), rostrum (except at extreme base), antennae (except club) and legs (the femora somewhat infuscate in middle) red. Densely clothed with white or whitish and almost uniform scales.

Rostrum rather thin, feebly curved, slightly longer than prothorax; parallel sided and with five fine earinae to insertion of antennae; in front of same slightly diminishing in width, with the median carina for a short distance and with a few punctures. Antennae inserted about one-third from apex of rostrum; scape almost as long as funicle; first joint of funicle moderately stout, distinctly longer than second. Prothorax about once and one half as wide as long, sides strongly rounded, base much wider than apex; with dense but normally concealed punctures. Elytra elongata - subcordate, about once and two — thirds the width of prothorax; with rows of rather large but normally almost concealed punctures. Under surface 
with dense but normally concealed punctures; two basal segments of abdomen with a large shallow median depression, common to both. Length $3 \mathrm{~mm}$.

Hab. - Australia (Berlin Museum); W. Australia: Beverley, Swan River (A. M. Lea).

In Blackburn's table of the Erirhinides this species would certainly be placed in Dicomada, and it agrees with Pascoe's diagnosis of that genus, except in the comparative widths of prothorax and elytra. From the only species (litigiosa and mefa) known to me it is readily distinguished by its comparatively small prothorax; the claw joint is longer than in litigiosa. In some respects it agrees with the diagnosis of Paryzeta, but the scape does not attain the eye.

The Museum specimen is probably a female, it differs from my own specimens (both probably males) in having the rostrum without carinae, but with distinct punctures; in the males these being (except towards the apex) more or less concealed by the clothing.

\section{Amalactides.}

170. Tranes internatus, Pasc.

171. T. xanthorrhoeae, Lea.

\section{Belides.}

\section{Belus phoenicopterus, Germ.}

A specimen from Adelaide differs from the typical form in having the elytra with very distinct spots close to the suture, and the nitid spot on the side pieces of the metasternum very small and round.

\section{Belus filiformis, Germ.}

The male ( $\mathrm{I}$ have a pair which were taken in cop) of this species differs from the female in being smaller, slightly narrower, with considerably thinner femora and shorter rostrum, the base of which has coarser punctures. In both sexes the femora are edentate. In three specimens (all females) the clothing of the legs (and to a certain extent of the rest of the body) is looser and longer than in six other specimens (four males and two females) but I can find no other characters to warrant their separation.

A specimen is in the Berlin Museum from Adelaide, but the species is fairly common both in South Australia and N. S. Wales.

174. B. acicularis, Pasc.

175. B. bidentatus, Don.

176. B. bimaculatus, Pasc.

177. B. brunneus, Guer.

178. B. centralis, Pasc.

179. B. hemistictus, Germ.

180. B. irroratus, Jek.

181. B. picus, Jek.

182. B. plagiatus, Pasc.

183. B. punctirostris, Lea. Hab. - Adelaide. 
184. B. scalaris, Germ.

185. B. semipunctatus, Fab.

186. B. sparsus, Germ.

187. Pachyura australis, Hope.

188. P. congesta, Pasc.

189. P. dermestiventris, Boi, var. fumigata, Germ

190. P. minima, Blackb. Hab. - Melbourne.

191. Rhinotia elytrura, Pasc.

192. R. pruinosa, Pasc.

\section{Eurhynchides. \\ 193. Eurhynchus acanthopterus, Boi.}

\section{Apionides.}

194. Apion terrae-reginae. Blackb.

\section{Attelabides.}

\section{Euops strigiventris, Lea.}

The type of this species is a female. There are now before me a number of specimens of both sexes from Queensland (Berlin Museum), N. S. Wales (Entomological Society of Berlin), and Clarence River, Ash Island and Illawarra (Macleay Museum).

The male differs from the female in having the head thinner and almost twice as long; the rostrum thinner, longer and more noticeably inflated towards apex. The prothorax is longer; the elytra are more dilated across shoulders. All the legs are longer, but the front femora and tibiae are much longer (longer than in any other species known to me). The front femora are strongly arched and thin towards the base, and strongly inflated (although to a less extent than in falcata) towards the apex. The front tibiae are about as long as the femora and longer than the elytra, thin, strongly curved, and without the minute denticulations that many other species have.

The elytra usually have a purplish gloss, but sometimes the gloss is greenish; or they may be almost black.

\section{E. Bakewelli, Jek. \\ 197. E. falcata, Guer.}

\section{Tychiides.}

198. Elleschodes tenuirostris, n. sp.

Of a rather deep chestnut-brown; under surface black. Upper surface with straw coloured stout setae irregularly distributed, the interspaces with much finer and sparser pubescence; under surface and legs with whitish pubescence, denser on sides of meso- and metasternum than elsewhere.

Rostrum thin; in male slightly longer than prothorax, in female distinctly longer; moderately curved, with a narrow median carina from base to apex, and 
with rows of punctures causing an appearance as of four other but more feeble carinae; sculpture almost concealed by clothing on basal third in male, at base only in female. Antennae thin, inserted at about two-fifths from apex; but in male slightly closer to apex than in female. Prothorax about once and one half as wide as long; with dense, fairly large and round, but more or less concealed punctures, and usually with traces of a very feeble median carina. Elytra elongate-cordate, parallel-sided from near the base to beyond the middle; striate-punctate, striae and punctures both rather narrow towards the suture, becoming larger and wider towards the sides; interstices scarcely separately convex, with small scattered punctures. Abdomen with dense punctures; suture between first and second segments almost obsolete in middle, fifth convex in male, feebly depressed across middle in female. Femora stout, strongly and acutely dentate. Length $2^{1 / 3}-3^{1} / 2 \mathrm{~mm}$.

Hab. - Tasmania.

The apical segment of the abdomen is often diluted with red; the base of the front femora is often stained with black, as are also the sides of the elytra towards the base. The straw coloured setae are dense between the eyes, on each angle of the prothorax and in the middle of its base, and form two irregular fasciae on the elytra - one at base and one at summit of posterior declivity, they are also fairly dense about the apex of the elytra and on the feeble preapical callosities. On the prothorax, however, they are sometimes fairly evenly distributed except about the middle. It is the largest of the near allies of eucalypti.

A specimen from the Berlin Museum and one from Mons. A. Bovie were labelled Australia. All my own numerous specimens were taken near Hobart.

\section{Laemosaccides.}

\section{Laemosaccus hieroglyphicus, n. sp.}

Black, in places red or diluted with red. Densely but irregularly clothed with more or less ochreous setose pubescence, parts of elytra and most of under surface with whitish pubescence, more or less mixed with a whitish meal.

Head with dense but usually concealed punctures. Rostrum of male rather short, almost straight, with dense and coarse but more or less concealed punctures; of female longer, somewhat shining, feebly but noticeably curved, and with smaller and sparser punctures, but not concealed except at extreme base. First joint of funicle stout, longer than second; club of male stout and as long as funicle; of female smaller and distinctly shorter than funicle. Prothorax as long as wide; densely granulate-punctate; with a median line, feeble in middle but deeper polished in front and behind; an almost circular, shining, impunctate depression on each side of base. Elytra punctate-striate; interstices densely and finely punctate, and with a few inconspicuous granules. Pygidium with a strong median keel almost angularly raised in its middle. Front femora very feebly dentate, the others edentate; front tibiae shorter and wider than usual. Length $53 / 4-61 / 2 \mathrm{~mm}$.

Hab. - Queensland (Berlin Museum); N. S. Wales: Blue Mountains (Macleay Museum), Muswellbrook (E. W. Ferguson), Jindabyne (H. J. Carter), Braidwood (A. M. Lea). 
The rostrum varies from being entirely of a dingy red to almost entirely black, but is sometimes half red and half black, the two colours being rather clearly limited. The prothorax is usually black except at the apex, but a specimen in M. Carters cellection has a feebly defined and irregular reddish fascia near its base. The elytra are usually of a dingy brown more or less diluted with red, but in the Berlin Museum specimen are black, except that the sides and apex are narrowly diluted with red; in the Macleay Museum specimen (the only male before me) they are reddish with apparently remnants of three blackish fasciae - one at basal third, extending halfway to suture, one at middle extending slightly nearer to suture, and one near apex almost touching suture. On several other specimens these remnants of fasciae appear to be present but very feebly defined. The black parts of the legs vary in extent, but the knees and tarsi are always reddish, as are also the antennae. On the elytra in well preserved specimens the white pubescence (which, however, is sometimes slightly ochreous) forms a large basel patch interrupted by the shoulders, at the basal third suddenly extends in the form of a narrow fascia to the sides, then is narrowly continued along the suture, and again (slightly beyond the middle) suddenly extends in the form of a narrow fascia to the sides and terminates. The white pubescence is usually covered with a dense whitish meal, rendering it all the more conspicuous; but the meal becomes lost in fluids, so that on specimens collected in spirits or at all abraded the bifasciate appearance is rather inconspicuous. The clothing between the eyes, on prothorax and at apex of elytra is occasionally reddish instead of ochreous. The median line of the prothorax appears almost as if seared in in front.

200. L. brevipennis, Pasc.

201. L. carinicollis, Lea.

202. L. frater, Lea.

203. L. subsignatus, Boh.

\section{Haplonycides.}

\section{Haplonyx Spencei, Gyll.}

This species is widely distributed in N. S. Wales, Victoria and Tasmania, and specimens before me range in length from 5 to $9 \mathrm{~mm}$.

\section{Variety A.}

Five specimens from Adelaide (Belgian and Berlin Museums) and Victoria (C. French) differ from the normal form in having the prothoracic scales almost uniformly yellowish-white or white; with the fascicles composed of almost golden brown scales, not at all tipped with black or dark brown. On the elytra the subapical fascia is wider and more distinct (on two specimens it practically extends to the apex itself), and the dark scales before it are less distinct, and only the posterior fascicles and the one behind the scutellum are tipped with black. In the normal form, however, all of the elytral fascicles are not always tipped with black.

This form when placed side by side with typical specimens of Spencei, certainly appears te be distinct, but I can find no structural differences between them. 
205. Haplonyx longipilosus, Lea.

The type of this species is a male, and its funicle was wrongly described as six-jointed, owing to the seventh joint being closely applied to the club and somewhat dirty. There are now several specimens of both sexes before me from Australia (Berlin Museum), K. G. Sound, Swan River and Port Lincoln (Belgian Museum), Mount Barker (R. Helms), and Bridgetown and Pinjarrah (A. M. Lea). The female differs from the male in having the rostrum considerably longer than head and prothorax combined (on a specimen measuring $5 \mathrm{~mm}$ the rostrum is $3 \frac{1}{2} \mathrm{~mm}$ ), and with the scape not extending to apex of rostrum, instead of distinctly passing it. In the elytral striae there are frequently isolated stout white scales, but these appear to be very deciduous.
206. H. centralis, Pasc.
207. H. cionoides, Pasc.
208. H. fasciculatus, Boh.
209. H. Macleayi, Chev.
210. Geopus storeoides, Pasc.

\section{Cryptorrhynchides.}

\section{Melanterius leptorrhynchus, n. sp.}

Black, in parts diluted with red. Under surface and legs with whitish setae, a single seta in each prothoracic puncture.

Head with small dense and regular punctures. Separation of eyes about half the width of rostrum. Rostrum long, thin and lightly curved, extending almost to hind coxae; with dense and rather small punctures on basal half, smaller and sparser elsewhere. Antennae thin, inserted slightly nearer apex than base of rostrum; first joint of funicle almost as long as second and third combined, second distinctly longer than third. Prothorax with dense, clearly defined punctures, becoming smaller towards apex, and nowhere confluent; without median line. Elytra considerably wider than prothorax; with regular rows of large and ather distant punctures or foveae; interstices regularly and acutely carinated (somewhat obtusely towards base), and each with a row of distinct punctures on each side. Under surface with dense punctures, larger on metasternum than elsewhere, but forming a single row on each of its side pieces. Femora moderately but the hind pair very strongly dentate; each with a small granule or supplementary tooth in the emargination. Length $7 \frac{1}{2}-8 \frac{1}{2} \mathrm{~mm}$.

Hab. - Australia (Berlin Museum); N. Territory: Port Darwin (N. Davies).

Both specimens before me are probably females. One of them has the rostrum, antennae and parts of the legs rather feebly diluted with red; in the other the head, tip of prothorax, the elytra and the whole of the legs (except the coxae) are also diluted with red. In my table of species of the genus it should be placed next to bidentatus, from which it differs in the much longer rostrum, and in the conspicuous rows of punctures on the elytral interstices.

212. M. maculatus, Lea.

213. M. semiporcatus, Er. 


\section{Tyrtaeosus interstitialis, n. sp.}

Black, rostrum somewhat paler: antennae and claw joints of a dull red. Moderately densely clothed with stout, subsetose scales.

Head with dense partially concealed punctures. Rostrum stout, about twothirds the length of prothorax; with dense punctures, partially concealed at basal third. Antennae rather stout, first joint of funicle distinctly longer than second. Prothorax moderately convex and transverse, sides strongly rounded, base bisinuate and twice the width of apex, with a continuous but not acute median carina; with dense, round and clearly defined but rather shallow punctures. Scutellum round but with a short basal, projection. Elytra not much wider than prothorax, sides feebly rounded to beyond the middle; with regular rows of rather large, elongate, suboblong punctures; interstices flat, not alternately raised, considerably wider than punctures, themselves with dense and rather coarse punctures. Mesosternal receptacle strongly raised in front, widely U-shaped. Side pieces of metasternum with dense punctures in two irregular rows. Abdomen somewhat flattened; with fairly dense punctures; second segment about two thirds the length of first, and once and one fourth the length of third; third and fourth with punctures as on the other segments. Legs rather short, femora moderately dentate. Length $8-10 \mathrm{~mm}$.

Hab. - S. Australia: Adelaide (Berlin and Belgian Museums).

Most of the scales are of a dull stramineous colour and rather closely applied to the derm, but on the elytra many of them are of a dingy brown, and so placed as to cause a feeble mottled appearance. The scutellum is of unusual shape.

Regarding the prothorax as rather feebly carinated then in the table previously given by me, it should be placed with ichthyosomus, from which it may be distinguished by its larger size, by the carina extending to both base and apex, and by the third and fourth abdominal segments and the side pieces of the metasternum with dense punctures. It is rather more elliptic in outline than the majority of species of the genus, and in general appearance is somewhat suggestive of Therebiosoma and Pseudotherebus, but the cavernous mesosternal receptacle readily distinguishes it from those genera.

215. T. cinerascens, Lea. Hab. - Tasmania.

216. T. imitator, Lea.

217. T. religiosus, Lea.

218. Perissops mucidus, Pasc.

219. P. rubiginosus, Lea. Hab. - Cape York.

220. Enteles Vigorsi, Gyll.

221. Cryptorrhynchus stigmaticus, Pasc.

222. Mechistocerus dispar, Lea. Hab. - Cape York.

223. Glochinorrhinus Doubledayi, Waterh.

224. Axionicus insignis, Pasc.

225. Aonychus Hopei, Boh.; A. Hopei var. bicruciatus, Lea.

226. A. luctuosus, Pasc.

227. Chaetectetorus bifasciatus, Boh.

228. Deretiosus blandus, Lea. Hab. - Cape York. 
229. Ephrycus obliquus, Pasc.

230. Metacymia marmorea, Pasc.

231. Mitrastethus Australiae, Lea.

232. Achopera lachrymosa, Pasc.

233. Acrotychreus fasciculatus, Lea. Hab. - Cape York.

234. Isax planipennis, Lea.

235. Euthyrrhinus meditabundus, Fabr.

236. E. spinipennis, Waterh.

237. Odosyllis crucigera, Pasc.

238. Psepholax humeralis, Lea. Hab. - Wide Bay.

239. Neozeneudes dives, Lea.

240. Exithius capucinus, Pasc.

241. Tragopus plagiatus, Pasc.

242. Protopalus cristatus, Pasc.

\section{Amethylus triangularis, n. sp.}

Black, antennae dull red, club darker. Clothing much as in lumbaris, except that the apex of prothorax is scarcely fasciculate, and that the abdomen is almost regularly clothed.

Head with a feeble median ridge. Rostrum shorter than prothorax, apex with a feeble subtriangular plate. First joint of funicle considerably longer than second. Prothorax triangular longer than wide; an obtuse ridge on each side, traceable at base but very distinct about middle and almost conjoined at apex; apex produced and considerably overhanging head. Elytra more triangular than in lumbaris; third interstice strongly elevated from near base to apical fourth, fifth elevated close to base. Basal segment of abdomen with a very feeble median ridge, commencing at its middle and continued to middle of second. Punctures and other characters as in lumbaris. Length $10 \mathrm{~mm}$.

Hab. - Queensland (Berlin Museum); N. S. Wales: Byron Bay (A. H. H a m m o n d).

Very closely allied to lumbaris, which it resembles even in the unusual markings, but it may be readily distinguished by the prothorax being longer than wide, very decidedly triangular, and considerably produced instead of tuberculate at apex; the alternate interstices of the elytra are also very different. Three specimens are labelled as having been seen "Devouring native passion fruit".

\section{Omydaus oblongopunctatus, n. sp.}

Rather sparsely clothed with stout ochreous, scales, each of which (except those on elytra) is set in a puncture; with more numerous sooty-black scales, which are of a more setose character, and occasionally are shining.

Head coarsely punctate; with or without a feeble median carina; eyes moderately faceted. Rostrum almost parallel sided; coarsely and almost equally punctate. Scape shorter than funicle. Prothorax moderately convex, sides rounded, base bisinuate; median carina distinct; with dense, large, round and not very shallow punctures. Elytra élongate subcordate, base equally trisinuate; with series of very 
large, deep, oblong punctures, becoming smaller and irregular towards sides and disappearing posteriorly; interstices punctate, feebly granulate, almost equal in width, the alternate ones scarelly visibly raised. Metasternum and basal segment of abdomen with large round punctures; apical segment densely punctate, three intermediate segments each with about two irregular rows of not very small punctures. Front tibiae as in subfasciculatus. Length $6^{1} / 3 \mathrm{~mm}$.

Hab. - Australia (Berlin Museum); N. S. Wales: Glen Innes (A. M. Lea).

In appearance approaches fuliginosus, but, besides being considerably smaller and differently clothed, the alternate interstices of the elytra are scarcely visibly raised and the punctures are much larger.

245. O. fuliginosus, Boi.

246. Stenoporopterus canaliculatus, Lea.

247. Poropterus intermedius, Lea.

248. P. Jekeli, Waterh.

249. P. Parryi, Waterh.

250. P. zopherus, Lea.

251. Euryporopterus funereus, Lea. Hab. - Melbourne.

252. Paleticus pedestris, Pasc.

253. P. subereus, Pasc.

\section{Calandrides.}

254. Sipalus gigas, Fabr:

255. Diathetes morio, Pasc.

\section{Cossonides.}

256. Cossonus Simsoni, n. sp.

Black, legs and antennae dark red.

Head with small and not very dense punctures; interocular fovea deep but rather small. Rostrum suddenly and strongly inflated at antennae, the inflated portion wider than long; not depressed along middle, punctures denser than on head, and, in places, slightly coarser. Prothorax gently convex, base feebly bisinuate; with dense and not very small punctures, becoming sparser but no larger towards middle, middle itself with remnants of a very feeble impunctate line, but the punctures at base more crowded than elsewhere. Elytra gently convex, with regular rows of large punctures, becoming smaller posteriorly; interstices each with a row of very minute punctures. Length $5-7 \mathrm{~mm}$.

Hab. - Tasmania (Berlin Museum and L. Rodway), Beaconsfield, Gould's Country, Launceston (A. Simson), Frankford, Hobart (A. M. Lea).

The comparatively smooth prothorax will readily distinguish from impressifrons, and the same part being without a triangular basal patch of very coarse punctures from excavatus. The rostrum is shaped more like a spade than in any other species known to me. Several specimens are of a dark reddish brown or piceous, with the under surface paler, but this is probably due to immaturity. 
257. C. praeustus, Redt.

258. Pentamimus canaliculatus, Woll.

259. Phloeophagosoma polixum, Er. (Rhyncolus).

A specimen labelled "Rhyncolus prolixus Er. Type? Terr Van Diem Schayer" agrees well with the description of this species, and is probably the type, or a co-type. The species was omitted from Masters' Catalogue*). I have five specimens from Hobart, Swansea and Parattah, and all have the rostrum more or less diluted with red. In the museum specimen the rostrum is less noticeably diluted with red, and no mention is made of its colour in the original description. The funicle is seven jointed.

From the European $R$. ater (stated by Wollaston to be the type of Rhyncolus), it differs in being thinner, in having the rostrum longer and much thinner, the scape longer, thinner, and curved at apex, and the funicle and tarsi thinner. It appears to agree better with Phlaeophagosoma than any other genus described by IVollaston, and at present I can see no reason why it should not be referred to that genus.

*) Rhyncolus australus, Er., also omitted from the catalogue, I have from many parts of Tasmania; it varies from a dingy red almost to black. It is a Pentarthrum, differing from nigrum in having a shorter rostrum, and denser and smaller prothoracic punctures. 


\section{$2 \mathrm{BHL}$ Biodiversity Heritage Library}

1911. "Notes on Australian Curculionidae in the Berlin Museum. With descriptions of new species." Mitteilungen aus dem Zoologischen Museum in Berlin 5, 175-201.

View This Item Online: https://www.biodiversitylibrary.org/item/44276

Permalink: https://www.biodiversitylibrary.org/partpdf/1079

\section{Holding Institution}

American Museum of Natural History Library

\section{Sponsored by}

Biodiversity Heritage Library

\section{Copyright \& Reuse}

Copyright Status: Public domain. The BHL considers that this work is no longer under copyright protection.

This document was created from content at the Biodiversity Heritage Library, the world's largest open access digital library for biodiversity literature and archives. Visit BHL at https://www.biodiversitylibrary.org. 